\title{
Aplikasi Ekstrak Daun Binahong (Anredera cordifolia (Ten) Steenis) dalam Air Minum terhadap Kualitas Karkas Ayam Jawa Super
}

\section{Application of Binahong (Anredera Cordifolia (Ten) Steenis) Leaf Extract in Drinking Water on Super Java Chicken Carcass Quality}

\author{
T Afandi ${ }^{1}$, A. A. Candra ${ }^{1 *}$, dan N. Irwani ${ }^{1}$ \\ ${ }^{1}$ Jurusan Peternakan Politeknik Negeri Lampung, \\ Jln. Soekarno Hatta No 10 Rajabasa Bandar Lampung, 35144 \\ *E-mail korespondensi: adicandra@polinela.ac.id
}

\begin{abstract}
This research aims to identify how much the benefits of binahong leaf extract as a feed additive to the quality of super java chicken carcasses. This research was conducted in the Cage and Laboratory of Lampung State Polytechnic Livestock Department. The material used in this study was 100 super Java chicken day old chick (DOC) that was placed in a stage cage with a size of $100 \mathrm{~cm} \times 100 \mathrm{~cm}$ and a height of $60 \mathrm{~cm}$ per plot. The research design used a complete random design with 5 treatments and 3 replays. P1: without treatment; P2: binahong leaf extract $250 \mathrm{mg} / \mathrm{kg}$ body weight; P3: binahong leaf extract 500 $\mathrm{mg} / \mathrm{kg}$ body weight; P4: binahong leaf extract $750 \mathrm{mg} / \mathrm{kg}$ body weight and P5: binahong leaf extract $1.000 \mathrm{mg} / \mathrm{kg}$ body weight. The results of the variety analysis showed that the use of binahong leaf extract on carcass quality had affect $(P>0.05)$ on the life weight and weight of carcasses, but did not affect the percentage of carcasses, the percentage of cooking shrink and the $\mathrm{pH}$ of meat, doses $1.000 \mathrm{mg} / \mathrm{kg}$ of body weight showed the best results on live weight and carcass weight of the super java chicken.
\end{abstract}

Keywords: binahong, carcass quality, super javanese chicken

Diterima: 1 Maret 2021, disetujui 15 Desember 2021

\section{PENDAHULUAN}

Ayam kampung atau ayam buras merupakan salah satu jenis ternak unggas yang sering dipelihara oleh masyarakat di daerah pedesaan. Ayam kampung mempunyai kelebihan pada daya adaptasinya yang tinggi (mampu menyesuaikan diri dengan berbagai situasi, kondisi lingkungan dan perubahan iklim serta cuaca setempat) sehingga tingkat mortalitas relatif rendah. Ayam kampung memiliki beberapa kekurangan, salah satunya yaitu, pertumbuhan yang cenderung lebih lambat dibandingkan broiler.

Ayam jawa super merupakan solusi untuk memenuhi permintaan daging ayam kampung yang dimana saat ini sulit jika hanya mengandalkan pasokan dari ayam kampung murni. Ayam jawa super adalah hasil persilangan antara betina ayam ras petelur dengan pejantan kampung. Hasil dari persilangan tersebut memiliki pertumbuhan lebih cepat dibandingkan ayam kampung murni (Agus dan Listyo, 2017)

Meningkatnya permintaan daging ayam kampung untuk memenuhi kebutuhan konsumen, terdapat kendala yaitu rendahnya bobot panen sehingga menghasilkan bobot karkas yang rendah sehigga perlu alternatif bahan alami yang bisa ditambahkan kedalam air minum yang diharapkan dapat meningkatkan bobot karkas. Solusi untuk mengatasi masalah tersebut dilakukannya penelitian pemberian ekstrak daun binahong yang diberikan melalui air minum yang diharapkan mampu meningkatkan kualitas karkas ayam jawa super. 
Daun binahong memiliki kandungan senyawa aktif yang berpotensi sebagai feed additive. Berdasarkan hasil penelitian yang telah dilakukan Rachmawati (2008), daun binahong mengandung beberapa senyawa aktif seperti saponin, terpenoid, flavonoid, dan minyak atsiri. Berdasarkan penelitian Irwani dan Candra, (2020), bahwa ekstrak daun binahong dalam air minum dengan dosis pemberian sampai $100 \mathrm{mg} / \mathrm{kg}$ mempengaruhi bobot hidup dan organ visceral (bobot hati, ventriculus, dan usus halus) ayam broiler, namun belum ditemukan dosis terbaik. Pemberian ekstrak daun binahong dalam air minum diharapkan mampu meningkatkan daya tahan badan ayam sehingga kualitas karkas ayam jawa super baik.

\section{METODE PENELITIAN}

Penelitian ini dilaksanakan di Kandang dan Laboratorium Jurusan Peternakan Politeknik Negeri Lampung. Ayam yang digunakan pada penelitian ini adalah ayam jawa super produksi PT. Citra Lestari Farm sebanyak 100 ekor yang dipelihara selama 60 hari. Ransum yang digunakan pada penelitian ini yaitu ransum komersil BR-I dan BR-II produksi PT. Japfa Comfeed yang diberikan secara adlibitum. Air minum yang digunakan dalam penelitian ini berupa air yang ada di sekitaran kandang dan diberikan secara $a d$ libitum. DOC yang telah tiba ditimbang untuk mengetahui bobot badan awalnya, kemudian memasukkan ke dalam brooder dan berikan larutan gula sebanyak 2 g/liter. DOC berada dalam brooder selama 7 hari. Setelah lepas dari brooder, maka DOC dibagi ke dalam 20 petak kandang percobaan secara acak. Setiap unit percobaan terdiri dari 5 ekor ayam. Semua petak kandang diberi label perlakuan untuk memudahkan pelaksanaan penelitian.

\section{Pembuatan ekstrak daun binahong}

Ekstrak daun binahong diekstraksi menggunakan metode maserasi (Hasiib et al., 2015). Menyiapkan daun binahong segar yang sudah dipisahkan dari batangnya, mencuci daun binahong dan dilakukan pemotongan dengan ukuran $3-5 \mathrm{~cm}$, kemudian dioven dengan suhu $60^{\circ} \mathrm{C}$ selama 5 jam, selanjutnya daun binahong digiling hingga halus kemudian lakukan pengayakan. Tahap ekstraksi dilakukan dengan menimbang tepung daun binahong sesuai dosis perlakuan, merendam tepung menggunakan aquadest selama 24 jam dengan perbandingan aquadest yang digunakan untuk merendam yaitu setengah dari kebutuhan air minum.

\section{Aplikasi ekstrak daun binahong}

Ayam jawa super berumur $1-7$ hari tanpa perlakuan, sedangkan pada umur $8-60$ hari diberikan larutan ekstrak daun binahong pada jam 9 setelah dipuasakan selama 2 jam kemudian setelah habis, diberikan air biasa secara ad libitum.

\section{Pengambilan Sampel}

Pengukuran peubah dilakukan setelah ayam berumur 60 hari, sebelum dipotong ayam dipuasakan 6 jam lalu ditimbang bobot hidupnya. Tujuan pemuasaan adalah untuk mempermudah pengolahan dan mencegah karkas kontaminasi dengan feses. Sampel diambil 10\% dari jumlah ayam perpetak. Menurut Nova et al. (2002), pengambilan sampel $10 \%$ telah mewakili populasi. Setiap petak kandang diambil sampel sebanyak 1 ekor, jumlah ayam yang dipotong adalah 15 ekor.

Pemotongan ayam dilakukan dengan metode kosher yaitu memotong vena jugularis, artericarotis, esophagus dan trachea. Kemudian ayam di celupkan ke dalam air panas $\left(65-80^{\circ} \mathrm{C}\right)$, selanjutnya dilakukan pembersihan bulu, organ dalam dan isi saluran pencernaan dikeluarkan kemudian dibersihkan. Dilanjutkan dengan penimbangan bobot karkas selanjutnya karkas dipotong pada bagian dada sebagai sampel untuk menghitung susut masak. 


\section{Metode Penelitian}

Metode penelitian dilakukan secara eksperimental menggunakan Rancangan Acak Lengkap (RAL), terdiri dari 5 perlakuan dan 3 ulangan. Masing-masing ulangan terdiri atas 5 ekor ayam. Perlakuan dosis ekstrak daun binahong terdiri atas :

P1 : $0 \mathrm{mg} / \mathrm{kg}$ bobot badan

$\mathrm{P} 2: 250 \mathrm{mg} / \mathrm{kg}$ bobot badan

$\mathrm{P} 3: 500 \mathrm{mg} / \mathrm{kg}$ bobot badan

$\mathrm{P} 4: 750 \mathrm{mg} / \mathrm{kg}$ bobot badan

P5 : $1.000 \mathrm{mg} / \mathrm{kg}$ bobot badan

Data yang diperoleh dari hasil penelitian dilakukan analisis ragam, jika hasil analisis ragam menunjukkan hasil berpengaruh nyata, maka dilanjutkan dengan Uji Beda Nyata Terkecil (BNT) pada taraf $5 \%$ (Steel, 1991).

\section{Peubah yang Diamati}

1. Bobot hidup

Pengukuran bobot hidup (g/ekor) dilakukan dengan cara menimbang ayam percobaan diakhir pemeliharaan setelah dipuasakan selama 6 jam.

2. Bobot karkas

Bobot karkas (g) ditimbang berdasarkan bobot karkas ayam tanpa darah, bulu, kepala sampai batas bagian leher, kaki dan organ dalam.

3. Persentase karkas

Persentase karkas yaitu jumlah perbandingan antara bobot karkas dibagi dengan bobot hidup dikali $100 \%$.

4. $\mathrm{pH}$ daging

Pengecekan dilakukan menggunakan kertas $\mathrm{pH}$ sebanyak 3 kali setelah dilakukan pengecekan $\mathrm{pH}$ pertama sampel di diamkan selama 2 jam kemudian dilakukan pengecekan ulang pada 2 jam berikutnya.

5. Persentase susut masak

Susut masak di dapat dari penimbangan bobot awal sampel (bagian dada) dikurangi dengan bobot sampel setelah dilakukan pengukusan selama 15 menit kemudian dikalikan $100 \%$.

\section{HASIL DAN PEMBAHASAN}

Aplikasi ekstrak daun binahong pada air minum terhadap kualitas karkas ayam jawa super disajikan pada Tabel 1.

Tabel 1. Aplikasi ekstrak daun binahong pada air minum terhadap kualitas karkas ayam jawa super

\begin{tabular}{lccccc}
\hline \multirow{2}{*}{ Variabel } & \multicolumn{5}{c}{ Dosis Ekstrak Daun Binahong $(\mathrm{mg} / \mathrm{kg}$ bobot badan $)$} \\
\cline { 2 - 6 } & \multicolumn{1}{c}{0} & 250 & \multicolumn{1}{c}{500} & 750 & 1.000 \\
\hline $\begin{array}{l}\text { Bobot hidup } \\
\text { (g/ekor) }\end{array}$ & $1.043,33 \pm 77,18^{\mathrm{bc}}$ & $903,67 \pm 83,48^{\mathrm{a}}$ & $1.006,67 \pm 34,65^{\mathrm{b}}$ & $1.055,00 \pm 7,81^{\mathrm{bc}}$ & $1.109,00 \pm 15,62^{\mathrm{c}}$ \\
$\begin{array}{l}\text { Bobot karkas } \\
\text { (g/ekor) }\end{array}$ & $638,67 \pm 46,82^{\mathrm{bc}}$ & $552,00 \pm 57,17^{\mathrm{a}}$ & $630,00 \pm 26,00^{\mathrm{b}}$ & $673,67 \pm 14,01^{\mathrm{bc}}$ & $703,00 \pm 24,02^{\mathrm{c}}$ \\
$\begin{array}{l}\text { Persentase karkas } \\
(\%)\end{array}$ & $61,23 \pm 1,85^{\mathrm{a}}$ & $61,05 \pm 1,69^{\mathrm{a}}$ & $62,57 \pm 0,49^{\mathrm{a}}$ & $63,85 \pm 0,89^{\mathrm{a}}$ & $63,39 \pm 2,02^{\mathrm{a}}$ \\
$\begin{array}{l}\text { Persentase Susut } \\
\text { masak (\%) }\end{array}$ & $24,75 \pm 0,93^{\mathrm{a}}$ & $21,75 \pm 1,86^{\mathrm{a}}$ & $27,25 \pm 2,49^{\mathrm{a}}$ & $28,00 \pm 0,74^{\mathrm{a}}$ & $26,50 \pm 0,99^{\mathrm{a}}$ \\
Ph daging & $6,00 \pm 0,00^{\mathrm{a}}$ & $6,00 \pm 0,00^{\mathrm{a}}$ & $6,00 \pm 0,00^{\mathrm{a}}$ & $6,00 \pm 0,00^{\mathrm{a}}$ & $6,00 \pm 0,00^{\mathrm{a}}$ \\
\hline
\end{tabular}

Keterangan : rataan yang diikuti huruf yang sama yaitu tidak berbeda nyata pada BNT 5\% dan $1 \%$ 


\section{Pengaruh Perlakuan terhadap Bobot Hidup}

Hasil analisis ragam menunjukkan bahwa pemberian ekstrak daun binahong dalam air minum berpengaruh sangat nyata $(\mathrm{P}>0,05)$ terhadap bobot hidup ayam jawa super. Setelah dilakukan uji beda nyata terkecil rataan bobot hidup (g/ekor) pada perlakuan $1.000 \mathrm{mg} / \mathrm{kg}$ bobot badan memperoleh hasil terbaik yaitu $1.109,00$ g/ekor. Tingginya bobot hidup yang dihasilkan disebabkan oleh konsumsi ransum pada perlakuan ini juga tinggi. Konsumsi ransum pada perlakuan $1.000 \mathrm{mg} / \mathrm{kg}$ bobot badan (2.426,08 g/ekor). Diduga tingkat konsumsi ransum mempengaruhi laju pertumbuhan dan bobot akhir karena pembentukan otot, bentuk dan komposisi badan pada hakekatnya adalah akumulasi pakan yang dikonsumsi. Selanjutnya pengaruh perlakuan terhadap bobot hidup diduga senyawa aktif yang terkandung dalam ekstrak daun binahong sebagai antibiotik yang menggangu fungsi dari mikroorganisme patogen di dalam saluran pencernaan berperan baik, sehingga nutrisi dapat dimanfaatkan dengan optimal. Hal ini sesuai dengan pendapat (Rasyaf, 2011), bahwa konsumsi ransum merupakan cermin dari masuknya sejumlah nutrien ke dalam badan.

\section{Pengaruh Perlakuan terhadap Bobot Karkas}

Hasil analisis ragam menunjukkan bahwa pemberian ekstrak daun binahong pada air minum berpengaruh sangat nyata $(\mathrm{P}>0,05)$ terhadap bobot karkas ayam jawa super. Setelah dilakukan uji beda nyata terkecil rataan bobot karkas (g/ekor) pada perlakuan $1.000 \mathrm{mg} / \mathrm{kg}$ bobot badan memperoleh hasil terbaik yaitu 703,00 g/ekor. Tingginya bobot kakas yang dihasilkan dipengaruhi oleh bobot hidup pada perlakuan $1.000 \mathrm{mg} / \mathrm{kg}$ bobot badan memperoleh hasil tertinggi yaitu 1.109,00 gr/ekor. Hal tersebut sesuai dengan pendapat (Wulandari, 2012), bahwa bobot karkas diimbangi bobot hidup yang dipengaruhi oleh jumlah konsumsi ransum serta proses pencernaan dan penyerapan ransum secara optimal.

\section{Pengaruh Perlakuan terhadap Persentase Karkas}

Hasil analisis ragam menunjukkan, bahwa penggunaan ekstrak daun binahong di dalam air minum tidak memberikan pengaruh $(\mathrm{P}<0,05)$ terhadap persentase karkas ayam jawa super, diduga karena sampel tidak seragam pada bobot hidup dan jenis kelamin. Hal ini sesuai dengan Williamson dan Payne (1978), bahwa faktor yang mempengaruhi persentase karkas yaitu bangsa, jenis kelamin, umur, kondisi fisik dan lemak abdomen. Rataan persentase karkas ayam jawa super yang diberikan ekstrak daun binahong dalam air minum berkisar 61,236-3,85\%. Hasil penelitian ini sejalan dengan pendapat Sari et al. (2014), bahwa persentase karkas sebagai perbandingan antara berat karkas dengan berat hidup tidak selalu memperlihatkan berat hidup yang rendah akan menghasilkan persentase karkas yang semakin rendah pula.

\section{Pengaruh Perlakuan terhadap pH Daging}

Rataan nilai $\mathrm{pH}$ daging ayam jawa super yang diberikan ekstrak daun binahong dalam air minum setelah pemotongan (daging segar) dan pengecekan $\mathrm{pH}$ dilakukan sebanyak 3 kali (0, 2 dan 4 jam) setelah proses pemotongan disajikan pada tabel 3 di atas. Hasil penelitian ini memperlihatkan tidak adanya pengaruh $(\mathrm{P}<0,05)$ terhadap $\mathrm{pH}$ daging ayam jawa super. Adanya dugaan bahwa proses rigormortis belum terjadi saat 4 jam setelah pemotongan. Nilai $\mathrm{pH}$ pada perlakuan $250 \mathrm{mg} / \mathrm{kg}$ bobot badan sampai dengan perlakuan 1.000 $\mathrm{mg} / \mathrm{kg}$ bobot badan yaitu 6 yang diperoleh dari pengecekan secara berturut - turut mulai dari daging segar dan setelah didiamkan selama 2 dan 4 jam. Nilai tersebut sesuai dengan pernyataan (Herlina, 2013), bahwa nilai $\mathrm{pH}$ produk pangan Standar Nasional Indonesia yaitu 6-7. Perubahan $\mathrm{pH}$ daging setelah pemotongan dipengaruhi oleh ketersediaan asam laktat yang dipengaruhi oleh kandungan glikogen, dan kandungan glikogen dipengaruhi oleh penanganan ternak sebelum dipotong (Suradi, 2006). 


\section{Pengaruh Perlakuan Terhadap Persentase Susut Masak Daging}

Hasil analisis ragam menunjukkan, bahwa penggunaan daun binahong dalam air minum tidak memberikan pengaruh $(\mathrm{P}<0,05)$ terhadap persentase susut masak daging ayam jawa super. Hasil penelitian menunjukkan kisaran susut masak antara 21,75-28\%. Rataan susut masak daging ayam jawa super memperoleh hasil terendah pada perlakuan $250 \mathrm{mg} / \mathrm{kg}$ bobot badan yaitu $(21,75 \%)$ dimana hasil tersebut menunjukkan bahwa kualitas daging pada perlakuan ini memiliki kualitas lebih baik, karena tidak banyak kehilangan nutrisi selama pemasakan dibandingkan dengan perlakuan $750 \mathrm{mg} / \mathrm{kg}$ bobot badan memperoleh hasil tertinggi yaitu (28\%) yang banyak kehilangan nutsiri selama pemasakan. Hal tersebut sesuai dengan pernyataan Prayitno et al. (2010), semakin kecil susut masak berarti semakin sedikit air yang hilang dan nutrisi yang larut dalam air. Begitu juga sebaliknya semakin besar susut masak maka semakin banyak air yang hilang dan nutrisi yang larut dalam air. Selanjutnya Soeparno (2009), bahwa daging dengan susut masak lebih rendah mempunyai kualitas yang relatif lebih baik dibandingkan dengan susut masak yang lebih tinggi, karena kehilangan nutrisi selama pemasakan akan lebih sedikit.

\section{KESIMPULAN}

Berdasarkan hasil penelitian dan pembahasan, dapat disimpulkan bahwa penggunaan ekstrak daun binahong dalam air minum memberikan pengaruh sangat nyata terhadap bobot hidup dan bobot karkas ayam jawa super dan setelah dilakukan uji beda nyata terkeci memperoleh hasil terbaik pada dosis $1.000 \mathrm{mg} / \mathrm{kg}$ bobot badan menghasilkan rataan bobot hidup 1.109,00 g/ekor dan bobot karkas sebesar 703,00 g/ekor. Pemberian ekstrak daun binahong dalam air minum tidak memberikan pengaruh nyata terhadap persentase karkas, susut masak dan $\mathrm{pH}$ daging ayam jawa super yang dipelihara selama 60 hari.

\section{DAFTAR PUSTAKA}

Agus, S. M. dan Listyo, S. 2017. Beternak Ayam Kampung Joper (Jowo Super). Jakarta Selatan. Agromedia Pustaka.

Hasiib, E., Riyanti, R., dan Hartono, M. 2015. Pengaruh pemberian ekstrak daun binahong (Anredera cordifolia (ten.) Steenis) dalam air minum terhadap performa broiler. Jurnal Ilmiah Peternakan Terpadu 3(1): 14-22.

Herlina, A. L. 2013. Teknologi Pengawetan Pangan. Bandung. Alfabeta.

Irwani, N. dan Candra, A. A. 2020. Aplikasi ekstrak daun binahong (Anredera cordifilia) terhadap kondisi fisiologis saluran pencernaan dan organ viceral pada broiler binahong (Anredera cordifilia). Jurnal Peternakan Terapan 2(1): 22-29.

Nova, K., Kurtini, T., dan Riyanti. 2002. Manejemen Usaha Ternak Unggas. Bandar Lampung. Universitas Lampung.

Prayitno, A. H., Suryanto, E., dan Zuprizal. 2010. Kualitas fisik dan sensoris daging ayam broiler yang diberi pakan dengan penambahan ampas virgin coconut oil (VCO). Buletin Peternakan 34 (1):55-63.

Rachmawati, S. 2008. Makroskopi, Mikroskopi Dan Skrining Fitokimia Daun Binahong (Anredera Cordifolia (Ten.) Steenis) [Tesis]. Palembang: Universitas Airlangga.

Rasyaf, M. 2011. Panduan Beternak Ayam Pedaging. Edisi 15. Kanisius.

Sari, M. L., Lubis, F. N. L., dan Jaya, L. D. 2014. Pengaruh pemberian asap cair melalui air minum terhadap kualitas karkas ayam broiler. Jurnal Agripet 14 (1): 71—75. 
Soeparno. 2009. Ilmu dan Teknologi Daging. Edisi 2. Yogyakarta. Press.

Steel, R. G. D. 1991. Prinsip dan Prosedur Statistika. hal.735-748. Jakarta. Gramedia Pustaka Utama.

Suradi, K. 2006. Perubahan sifat fisik daging ayam broiler post mortem selama penyimpanan temperatur ruang. Jurnal Ilmu Ternak 6 (1): 23-27.

Williamson, G. dan Payne, E. M. 1978. An Induction Husbandry In The Tropic. Edisi 3. London.

Wulandari, M. 2012. Pengaruh Pemberian Asam Fulvat Dalam Ransum terhadap Bobot Karkas, Organ Dalam dan Kolesterol Daging Ayam Broiler. [Skripsi]. Bogor. Institut Pertanian Bogor. 